\title{
FINANCIAL AND ECONOMIC EVALUATION OF THE LIVESTOCK FUND OF THE AGRICULTURAL INITIATIVE IN IRAQ FOR THE PERIOD-2009)
}

\section{(2018}

\author{
M. H. O. Al khazeli* \\ Researcher \\ B. H. Al-Badri*** \\ Assist. Prof. \\ "Prime Minister's Office/ High Committee of the Agriculture Initiative \\ ${ }^{* *}$ Dept. of Agricultural Economics. Coll. of Agric ., University of Baghdad \\ mohemd83ty@yahoo.com \\ dr_basimbadri@yahoo.com
}

\begin{abstract}
The demand for livestock products (dairy, meat, eggs) is characterized by a continuous increase in its basic importance as well as being essential in the prevailing food pattern domestically. The livestock sector suffers from a problem of poor funding and the investor's inability to compete for several reasons, the most important of which is the high interest on loans granted by institutions. Borrowing, and since the project needs large capital, it will make the investor a loser without any doubt. The demand for livestock products is characterized by a continuous increase in its basic importance and its entry as a major component of the prevailing food pattern locally. With the exception of the governorates of Nineveh and Salah al-Din for the period (2009-2013), it decreased to less than $50 \%$ for the period (2014-2018) and the reason is due to the events that occurred in addition to the repeated postponement decisions for all loans within the Federal Budget Law. The rate of late loan collection is low in all governorates for the period studied (2009-2016), as the average did not exceed $62 \%$ in 2016, or the lowest average was in 2010 by $4.5 \%$, and the reason for this is that the projects that were lagged in repayment are either that the rates of completion Their operation is low from the beginning, or poorly managed and subject to repeated epidemiological injuries. The research also found that the rates of collection of the livestock fund increased, reaching the highest in $2012(87.3)$ with a standard deviation (0.202) and the lowest average in 2018 (43.1) with a standard deviation $(0.220)$ as it shows clearly the progress of the central and southern governorates over the other covered governorates.
\end{abstract}

Key words: financial evaluation, economic evaluation, livestock fund.

*Part of Ph.D. dissertation of the $\mathbf{1}^{\text {st }}$ author

الخزعلي والبدري

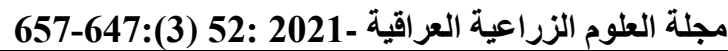

تقييم مالي واقتصادي لصندوق الثروة الحيوانية للمبادرة الزراعية في العراق للمدة (2009-2018)

$$
\text { باسم حازم حميد البلري }
$$

قسم الاقتصاد الزراعي ـ كلية الزراعة. جامعة بغداد
محمد حمزة عمران الخزعلي"

باحث

اللجنة العليا للمبادرة الزراعية/ مكتب رئيس الوزراء

المستخلص

يتصف الطلب على منتجات الثروة الحيوانية (البان، لحوم، بيض) بالتزايد المستمر لأهميته الاساسية ودخوله كمكون رئيس للنمط الغذائي السائد محليا،

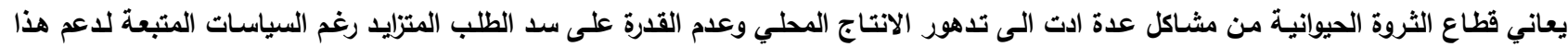
القطاع المهم والحيوي، الا ان الفجوة الغذائية بين الطلب والناتج المحليين كبيرة وهذا ما جعل للمنتجات المستوردة رواجـا واسـعاً فضـلا عن انفاق اموالا

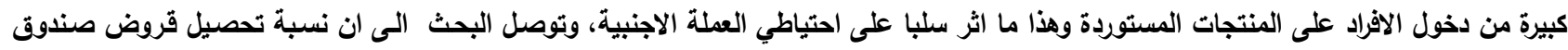
الثروة الحيوانية جيدة جدا وهي اعلى من 70\% في عموم المحافظات عدا محافظتي نينوى وصلاح الدين للمدة (2009-2013) الا انها انخفضت الى

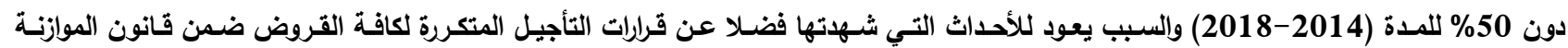

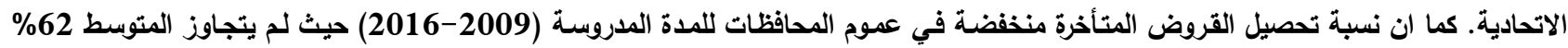
عام 2016 اما ادنى متوسط كان عام 2010 بواقع 4.5\% والسبب يعود في ذلتك الى ان المشاريع التي تلكأت في التسديد هي امـا ان نسب انجازها وتثغيلها متدنية منذ البداية او سوء ادارتها وتعرضها لإصابات ويائية متكررة. كما توصل البحث السى ان نسب تحصيل صندوق الثروة الحيوانية ارتفعت فئ حيث بـنغ اعلاهـا عام 2012 (87.3) بـانحراف معياري (0.202) وادنس متوسط كـان عام 2018 (43.1) بـانحراف معيـاري (0.220) كمـا يظهر واضحاً تقدم محافظات الوسط والجنوب على باقي المحافظات المشمولة. الكلمات المفتاحية: تقييم مالي ، تقييم اقتصادي، صندوق الثروة الحيوانية. "البحث مستل من أطروحة دكتوراه للباحث الأول.

Received:22/5/2020, Accepted:16/8/2020 


\section{INTRODUCTION}

Farming credit is provides for the purposes of production and development reasons 16, and its also one of the importance factor influencing substantially the output of agricultural production, the performance with loans is bater than without it 11 , the animal wealth in Iraq is one of the most prominent activities of the agricultural sector in terms of number and diversity, and it constitutes an important source of food in the country, but in recent years there has been a state of declining growth of livestock and its different types, such as poultry, fish, sheep, and buffalo cows, local experts confirm that Iraq have The massive development of this sector and raising the level of national production to compete with the importer and achieve self-sufficiency, and this case requires the responsible authorities to give the highest importance to this sector through preventive programs to prevent the occurrence and spread of infectious diseases to follow and spread modern education systems among educators, that the development of this important aspect in light of the existence of trends In general, relying on oil as a primary source of income without other sectors with long-term economic returns (1), and countries often resort as a result of the failure of their policies to undertake reforms through which they seek to influence their economies and make them compatible with developments The global economy due to the effect that these countries 'economies are having on each other and the emergence of international organizations and bodies as a fund The monetary and international bank strives to impose a single economic pattern governed by market mechanisms and the freedom of transfer of capital, an economic study of the impact of some agricultural policies on the major cereal crops in Iraq during the period (1994 - 2015), 5) and this was done by the Iraqi government in 2008 By launching the agricultural initiative that included several development programs, the most important of which were the specialized funds that included several funds, the most prominent of which was the Animal Resources Support Fund that specializes in financing agricultural projects / the animal side and for several different purposes and activities, including raising broilers, production of hatching eggs, table, hatcheries, cows, calves, buffalo, and sheep breeders in addition to fish lakes and floating cages, to address the problems that this vital sector has experienced in all governorates and the low levels of local production and dependence on imports at very high rates, especially after the opening that Iraq witnessed after 2003 to the global markets in importing different types of these products from various international marked, which caused the depletion of a large proportion of domestic incomes and transferred to neighboring countries to bridge the gap between the major producer a relatively low sophisticated and high local demand for these products, especially as the diversity of the product and the different tastes helped to form large local markets for goods produced abroad, which contributed to the exacerbation of the dumping problem and its attendant hard currency depletion on the one hand, and the inability of the Iraqi product to compete with these products in light of prices Low for the importer, and therefore we see that there is a great importance to adopt such projects to support the Iraqi product by providing capital with low or no interest for various agricultural and animal purposes specifically. The performance appraisal system level reflects the maturity and rationality of the community in facilitating its affairs and represents the tool by which we learn about the current reality (9), options for obtaining credit from lenders that include the farm credit system, commercial bank credit unions and government (18).

\section{MATERIALS AND METHODS}

Numbers of cows and buffalos and selfsufficiency ratios for both red and white meat, fish meat and eggs in Iraq (before and after loans): Table (1) shows that the highest number of cows was in $2008(2,552,113)$ followed by $2018(1,938,649)$ and the highest number of buffalos was also in 2008, fish meat production in 2013 was 105,168 tons, Due to the high number of fish farming projects in the floating and intensive cages, which led to the transformation of the method of breeding from lakes to floating cages, which is less expensive than lakes because they do not need diesel fuel to change the water of the dirt ponds and save 
large funds represented by the cost of operating water pumps for long hours throughout the duration of breeding, which may last to (six) months, as shown in table (1) that the highest production of table eggs was in 2012 where the total production (8.454) was a million eggs, the highest production of eggs in 2012., while table eggs production was 109,000 in 2007 . In the following period the launch of agricultural initiative loans, the production of table eggs increased significantly, reaching a peak in 2012 of $845,413,000$ eggs, but the dieses suffered by major projects produced throughout the provinces, the most famous of which are projects in the area of al wehda and al sawira. Mid-2016 was represented by Table 1 egg production projects, which caused the stop of those projects and their discontinuation of production led to a significant decrease in production for the year 2016, 2017, and production in that year reached 301,560 $(1,000$ eggs) for 2016. Table 1 also shows that the period (2009-2017) in which the selfsufficiency of red meat is higher than $60 \%$ unlike the previous period (2002-2008) as the rate of sufficiency is only $55 \%$ and the highest rate in 2014 was $139 \%$ This increase in selfsufficiency ratios is due to livestock fund loans to domestic imported lamb breeders, as well as support for feed factor projects in all provinces. In satisfactory proportions based on the growing population and the discontinuation of some major projects for the production of table eggs after 2003 such as those of Salah al-Din and Karbala, as well as the suffered by these projects in 2018 . 
Iraqi Journal of Agricultural Sciences -2021:52(3):647-657

Al khazeli \& Al-Badri

\begin{tabular}{|c|c|c|c|c|c|c|c|c|c|}
\hline $\begin{array}{c}\text { The } \\
\text { government's } \\
\text { support }\end{array}$ & Number of cows & $\begin{array}{c}\text { Number of } \\
\text { buffaloes }\end{array}$ & $\begin{array}{c}\text { Production } \\
\text { of red } \\
\text { meat/ton }\end{array}$ & $\begin{array}{c}\text { production of } \\
\text { Poultry meat } \\
\quad \text { /ton }\end{array}$ & $\begin{array}{l}\text { production of } \\
\text { Fish meat } \\
\text { /ton }\end{array}$ & $\begin{array}{l}\text { Production } \\
\text { of table eggs } \\
(1,000 \text { eggs })\end{array}$ & $\begin{array}{l}\text { Percentage of } \\
\text { self- } \\
\text { sufficiency of } \\
\text { red meat }(\%)\end{array}$ & $\begin{array}{l}\text { percentage of } \\
\text { sufficiency } \\
\text { for The } \\
\text { White House } \\
(\%)\end{array}$ & $\begin{array}{c}\text { percentage } \\
\text { Self- } \\
\text { sufficiency } \\
\text { for eggs }(\%)\end{array}$ \\
\hline 2002 & 1405000 & 128000 & 130500 & 122461 & 16015 & 170380 & 99.7 & 78.9 & 15.8 \\
\hline 2003 & 1426000 & 125000 & 131900 & 53191 & 18105 & 287538 & 74.6 & 75.0 & 41.4 \\
\hline 2004 & 1455000 & 128000 & 132000 & 46317 & 15495 & 420526 & 54.5 & 59.4 & 38.3 \\
\hline 2007 & 1547000 & 145000 & 138600 & 40258 & 41697 & 435145 & 51.6 & 28.2 & 35.1 \\
\hline 2008 & 2552113 & 285537 & 149700 & 36947 & 41432 & 460033 & 48.1 & 17.4 & 35.7 \\
\hline 2009 & 1613000 & 156000 & 152290 & 34087 & 44358 & 679431 & 62.7 & 16.1 & 51.1 \\
\hline 2010 & 1646000 & 162000 & 154950 & 87500 & 46381 & 731821 & 63.8 & 31.4 & 54.5 \\
\hline 2011 & 1679856 & 167903 & 157660 & 132000 & 46517 & 840691 & 63.7 & 74.4 & 62.6 \\
\hline 2012 & 1714595 & 174165 & 160466 & 171000 & 54936 & 845413 & 62.8 & 68.6 & 40.0 \\
\hline 2013 & 1750053 & 180662 & 163331 & 211614 & 105168 & 301560 & 71.9 & 67.9 & 26.6 \\
\hline 2018 & 1938649 & 216965 & & - & 75719 & & - & & 36.3 \\
\hline The average & 1711703 & 172637 & 151019.63 & 104168.94 & 46847.235 & 481099.38 & 70.5 & 60.4 & 36.3 \\
\hline
\end{tabular}

Source: 1. number of cows, number of buffalos, production of red and white meat and fish from the Central Bureau of Statistics - Agricultural Statistics,

2. The percentages of sufficiency from the calculation of researcher 


\section{Funding concept}

It is the provision of the money necessary for investment regardless of the multiple sources of this funding, either self or external, as it can be defined as the administrative field or a group of administrative jobs related to the management of the cash flow and its obligation to enable the institution to implement its goals and face the obligations it owes in due time all the executive actions that entail obtaining and investing cash in various operations helps to maximize the monetary value expected in the future in light of the cash currently available for investment, the expected return from it, the risks surrounding it and the trends of the financial market (4). The success of the evaluation process depends on the selection of appropriate indicators and criteria (10)

\section{Agricultural financing}

It is obtaining the necessary funds for the agricultural process to improve the level of agricultural products and their development, which contributes to raising the level of technology used in agricultural operations, and agriculture is classified as one of the most dangerous sectors from the point of view of most financial institutions from other economic sectors such as industry, trade and services, etc. Consequently, financial institutions tend to avoid providing financing for agriculture, especially for smallholder farmers who make up the largest proportion of the agricultural sector in developing countries 7. the most important standards used in evaluation:

\section{Payback Rate: / (3)}

It is the percentage of what is recovered from the loans that are due to be paid during a specific and specific period, which is usually the financial year of the lender and is calculated as follows:

Payback rate $=$

Total amounts collected during the fiscal year

\section{Total amounts due to be returned during the same year}

The rise in the collection percentage index is clear evidence that the lending agency is practicing its role correctly and performing its role successfully, and it must be pointed out that accuracy must be exercised when calculating the collection rate because it is an important indicator and clear evidence of what the institution has reached.

\section{Total amounts overdue at the end of the period}

Payback rate of the late loans $=$ 2-Payback rate of late loans (7):

It is expressed as the ratio of overdue amounts to loans that have not been paid in full or in part from the total loan balance granted during a specific time period and usually a fiscal year and that ratio can be found through the following relationship:

\section{The balance of the total loans at the end of the period}

This ratio is considered an improper indicator in case the loans are issued more quickly than the balances shift to maturity.

3- The time classification of arrears (4): Means the classification of amounts due or late for payment or collection of their dates into groups according to the period of their delay, and the ratio of each time period is calculated

Total amounts in arrears for the same period

Percentage of overdue sums for a certain period $=$ to the sum of the late amounts, and the time periods of the loans may be divided monthly, seasonally, quarterly, semi-annually or annually and are calculated as follows:

\section{4- Repayment Index (12)}

the sum of the arrears due for all periods.

This indicator is used to rank loans according to their repayment efficiency. This indicator can be found through the following mathematical equation: 


$$
R t=\frac{\sum_{t=1}^{n} A}{\sum_{t=1}^{n} A \max }
$$

$\boldsymbol{R} \boldsymbol{t}=$ life-time repayment index $\mathrm{T}$.

$$
=\sum_{t=1}^{n} A
$$

The cumulative sum of the amounts overdue during the life of the loan $t$, which extends from one year to $\mathrm{n}$ years, which represents the real state of repayment.

$\sum_{t=1}^{n} A \max$

The cumulative sum of the amounts that are overdue during the life of the loan $t$, which extends from one year to $n$ years, if we assume that the borrower has not paid any amounts.

The repayment index $R t$ ranges between (0-1), where 0 means complete default, and the correct one means full payment of the loans

Financial evaluation of the livestock fund

Table 2 shows the collection rates of the livestock fund loans for the period (20082018) for all governorates, 2009 the average and standard deviation (67.6, 0.31) respectively, the highest collection rate in this year for the governorates of Anbar and Muthanna by $(100 \%)$ and the lowest percentage was In Maysan Governorate $(0 \%)$, Al-Muthanna Governorate continued in the same percentage for the year 2010, followed by Najaf and Al-Qadisiyah governorates (99.7, $98.1 \%$ ), respectively, the lowest percentage was in Maysan Governorate (72.1\%). Dhi Qar
Governorate topped 2011, 2012 Ratios (81.8, $104.2 \%$ ) respectively, while Basra and Diyala governorates came last (17.1, 75.4\%) respectively, since 2013 DhiQar continued by $(98.9 \%)$ and ranked first also, and in 2014, Maysan was the first with ( $100 \%)$, and the lowest achievement rates for the previous two years are the governorates of Babylon and Karbala $(16.5,29.9 \%)$ respectively, and for the years 2015 and 2016, DhiQar and Maysan continued in first place with ratios $(100,98 \%)$ respectively, and the lowest in 2015 is Baghdad Governorate with a percentage (19\%), and in 2016 it was Wasit governorate $(15.7 \%)$, in 2017, Muthanna came first (82.5\%), and Qadisiyah in 2018 with For $(96.5 \%)$, the last rank in $2017(13.5 \%)$ in Wasit Governorate and $(0 \%)$ in Maysan Governorate in 2018, and the fluctuation in the collection rates of the livestock fund is due to the large number of postponement requests received by the Agricultural Cooperative Bank Administration and the Executive Office of the Supreme Committee the agricultural initiative mentioned in the recommendations of the field visit reports conducted by the follow-up teams of the office, due to the large number of injuries to livestock breeders in Iraq. The most prominent of these projects are broiler projects, and the most prominent of these injuries are (IP), Newcastle and others. The owners of hatching projects are usually affected by these injuries, and consequently, these projects are interlinked, which causes a sharp rise and decrease in the collection rates for all governorates.

Table 2. Percentage of collection of loans of the livestock fund for the period(2018-2009)

\begin{tabular}{|lcccccccccc|}
\hline The province & $\mathbf{2 0 0 9 \%}$ & $\mathbf{2 0 1 0 \%}$ & $\mathbf{2 0 1 1 \%}$ & $\mathbf{2 0 1 2 \%}$ & $\mathbf{2 0 1 3 \%}$ & $\mathbf{2 0 1 4 \%}$ & $\mathbf{2 0 1 5 \%}$ & $\mathbf{2 0 1 6 \%}$ & $\mathbf{2 0 1 7 \%}$ & $\mathbf{2 0 1 8 \%}$ \\
\hline Nineveh & $\mathbf{3 9 . 2}$ & $\mathbf{7 6 . 2}$ & $\mathbf{5 0 . 1}$ & $\mathbf{2 4 . 1}$ & $\mathbf{8 1 . 8}$ & $\mathbf{2 3 . 8}$ & $\mathbf{0}$ & & $\mathbf{0}$ & $\mathbf{0}$ \\
Salahaddin & $\mathbf{2 0 . 8}$ & $\mathbf{8 9}$ & $\mathbf{4 9 . 7}$ & $\mathbf{9 8 . 4}$ & $\mathbf{1 8 . 2}$ & $\mathbf{3 9}$ & $\mathbf{1 0 0}$ & $\mathbf{1 4 . 2}$ & $\mathbf{7 8 . 9}$ & $\mathbf{6 9 . 8}$ \\
Diyala & $\mathbf{7 4 . 3}$ & $\mathbf{9 1 . 8}$ & $\mathbf{7 2 . 5}$ & $\mathbf{7 5 . 4}$ & $\mathbf{9 3}$ & $\mathbf{3 8 . 8}$ & $\mathbf{5 1 . 6}$ & $\mathbf{5 4 . 2}$ & $\mathbf{1 7 . 6}$ & $\mathbf{4 8 . 8}$ \\
Kirkuk & $\mathbf{7 5}$ & $\mathbf{9 1 . 8}$ & $\mathbf{6 7 . 4}$ & $\mathbf{9 2 . 1}$ & $\mathbf{1 4 . 3}$ & $\mathbf{4 3 . 8}$ & $\mathbf{4 0 . 4}$ & $\mathbf{8 4 . 8}$ & $\mathbf{0}$ & $\mathbf{0}$ \\
Baghdad & $\mathbf{9 6 . 4}$ & $\mathbf{8 3 . 8}$ & $\mathbf{7 4 . 3}$ & $\mathbf{9 3 . 9}$ & $\mathbf{8 1}$ & $\mathbf{4 4 . 8}$ & $\mathbf{1 9}$ & $\mathbf{2 3 . 9}$ & $\mathbf{2 3 . 9}$ & $\mathbf{6 0 . 9}$ \\
Babylon & $\mathbf{8 4 . 5}$ & $\mathbf{7 9 . 5}$ & $\mathbf{1 5 . 6}$ & $\mathbf{9 9 . 1}$ & $\mathbf{1 6 . 5}$ & $\mathbf{5 6 . 3}$ & $\mathbf{5 3 . 8}$ & $\mathbf{4 2 . 3}$ & $\mathbf{4 6 . 9}$ & $\mathbf{6 6}$ \\
Karbala & $\mathbf{8 8 . 6}$ & $\mathbf{9 6 . 6}$ & $\mathbf{8 9 . 9}$ & $\mathbf{9 5 . 9}$ & $\mathbf{5 4 . 1}$ & $\mathbf{2 9 . 9}$ & $\mathbf{2 1}$ & $\mathbf{8 6 . 4}$ & $\mathbf{2 2 . 6}$ & $\mathbf{7 9 . 6}$ \\
Al Najaf & $\mathbf{3 3 . 1}$ & $\mathbf{9 9 . 7}$ & $\mathbf{2 7 . 9}$ & $\mathbf{9 0 . 8}$ & $\mathbf{7 2 . 4}$ & $\mathbf{3 5 . 2}$ & $\mathbf{3 3 . 2}$ & $\mathbf{2 1 . 7}$ & $\mathbf{1 3 . 7}$ & $\mathbf{8 1 . 8}$ \\
Al Qadisiyah & $\mathbf{7 9 . 6}$ & $\mathbf{9 8 . 1}$ & $\mathbf{8 6 . 5}$ & $\mathbf{9 9}$ & $\mathbf{6 9 . 5}$ & $\mathbf{3 7 . 9}$ & $\mathbf{3 2 . 6}$ & $\mathbf{8 9 . 4}$ & $\mathbf{3 7 . 6}$ & $\mathbf{9 6 . 5}$ \\
Anbar & $\mathbf{1 0 0}$ & $\mathbf{5 8 . 7}$ & $\mathbf{5 5 . 6}$ & $\mathbf{6 4 . 8}$ & $\mathbf{6 3 . 2}$ & $\mathbf{0}$ & $\mathbf{0}$ & $\mathbf{0}$ & $\mathbf{0}$ & $\mathbf{0}$ \\
Dhi Qar & $\mathbf{9 2 . 9}$ & $\mathbf{7 9 . 4}$ & $\mathbf{8 1 . 8}$ & $\mathbf{1 0 4 . 2}$ & $\mathbf{9 8 . 9}$ & $\mathbf{4 4 . 3}$ & $\mathbf{4 0 . 5}$ & $\mathbf{9 8}$ & $\mathbf{5 5 . 9}$ & $\mathbf{8 5 . 1}$ \\
Al muthana & $\mathbf{1 0 0}$ & $\mathbf{1 0 0}$ & $\mathbf{2 2 . 2}$ & $\mathbf{8 6}$ & $\mathbf{7 8 . 9}$ & $\mathbf{7 1 . 3}$ & $\mathbf{6 0 . 1}$ & $\mathbf{5 6}$ & $\mathbf{8 2 . 5}$ & $\mathbf{3 7 . 2}$ \\
Maysan & $\mathbf{0}$ & $\mathbf{7 2 . 1}$ & $\mathbf{2 2 . 9}$ & $\mathbf{9 2 . 1}$ & $\mathbf{5 5 . 3}$ & $\mathbf{1 0 0}$ & $\mathbf{1 0 0}$ & $\mathbf{3 9 . 9}$ & $\mathbf{2 1 . 1}$ & $\mathbf{0}$ \\
Basra & $\mathbf{5 0 . 8}$ & $\mathbf{9 2}$ & $\mathbf{1 7 . 1}$ & $\mathbf{9 6 . 8}$ & $\mathbf{4 6 . 1}$ & $\mathbf{3 8 . 8}$ & $\mathbf{9 0 . 8}$ & $\mathbf{6 5 . 2}$ & $\mathbf{3 5 . 1}$ & $\mathbf{8 3}$ \\
Wasit & $\mathbf{7 9 . 9}$ & $\mathbf{8 0 . 4}$ & $\mathbf{7 9 . 1}$ & $\mathbf{9 7 . 8}$ & $\mathbf{9 7 . 6}$ & $\mathbf{4 3 . 5}$ & $\mathbf{2 7 . 4}$ & $\mathbf{1 5 . 7}$ & $\mathbf{1 3 . 5}$ & $\mathbf{6 . 1}$ \\
The average & $\mathbf{6 7 . 6}$ & $\mathbf{8 5 . 9}$ & $\mathbf{5 4 . 1}$ & $\mathbf{8 7 . 3}$ & $\mathbf{6 2 . 7}$ & $\mathbf{4 3 . 1}$ & $\mathbf{4 4 . 6}$ & $\mathbf{4 9 . 4}$ & $\mathbf{2 9 . 9}$ & $\mathbf{4 7 . 6}$ \\
Deviation & $\mathbf{0 . 3 1 3}$ & $\mathbf{0 . 1 1 7}$ & $\mathbf{0 . 2 7}$ & $\mathbf{0 . 2 0 2}$ & $\mathbf{0 . 2 8 5}$ & $\mathbf{0 . 2 2}$ & $\mathbf{0 . 3 2 1}$ & $\mathbf{0 . 3 2}$ & $\mathbf{0 . 2 6 4}$ & $\mathbf{0 . 3 7}$ \\
\hline
\end{tabular}


Table 3 shows the rates of late loan collection for the Livestock Fund for the period (20092018) in all governorates, the lowest average in 2010 with a value of 4.5 , the highest collection rate of arrears for this year was in Anbar Governorate $(25.7 \%)$ and lowest in

Table 3. Percentage collection of delinquent loans to the Livestock Fund for the period (2009-

\begin{tabular}{|c|c|c|c|c|c|c|c|c|}
\hline The province & 2009 & 2010 & 2011 & 2012 & 2013 & 2014 & 2015 & 2016 \\
\hline Nineveh & 14.0 & 2.5 & 51.6 & 82.3 & 7.0 & 63.8 & $\mathbf{0}$ & $\mathbf{0}$ \\
\hline Salahdeen & 6.2 & 2.6 & 46.5 & 9.2 & 31.0 & 6.3 & 0.0 & 89.2 \\
\hline Diyala & 6.5 & 1.6 & 8.0 & 9.6 & 0.5 & 69.6 & 24.9 & 89.5 \\
\hline Kirkuk & 17.0 & 2.4 & 29.2 & 12.1 & 1.4 & 71.9 & 0.0 & 0.0 \\
\hline Baghdad & 0.4 & 6.7 & 12.3 & 4.0 & 5.7 & 49.3 & 84.6 & 76.0 \\
\hline Babylon & 13.0 & 7.7 & 14.5 & 23.3 & 66.7 & 40.1 & 26.7 & 90.5 \\
\hline Karbala & 12.8 & 1.0 & 4.8 & 2.6 & 11.9 & 94.8 & 39.8 & 56.5 \\
\hline alnajaf. & 18.5 & 0.1 & 45.9 & 0.5 & 18.9 & 26.1 & 11.0 & 101.4 \\
\hline Al Qadisiya & 25.9 & 0.5 & 3.5 & 0.2 & 1.6 & 36.4 & 31.4 & 92.4 \\
\hline Anbar & 0.0 & 25.7 & 85.1 & 76.8 & 78.6 & 0.0 & 0.0 & 0.0 \\
\hline Dhi Qar & 2.9 & 7.8 & 5.8 & 5.7 & 0.0 & 46.0 & 22.6 & 0.9 \\
\hline Al-Muthanna & 0.0 & 0.0 & 85.6 & 24.5 & 5.2 & 22.0 & 26.7 & 86.9 \\
\hline Maysan & 2.3 & 3.5 & 54.1 & 26.6 & 1.7 & $\mathbf{0 . 0}$ & $\mathbf{0 . 0}$ & 12.4 \\
\hline Basra & 10.5 & 1.1 & 56.1 & 0.2 & 1.0 & 30.6 & 25.1 & 73.4 \\
\hline Wasit & 27.1 & 4.5 & 12.4 & 40.9 & 1.1 & 97.4 & 101.0 & 95.8 \\
\hline Average & 34.6 & 4.5 & 34.3 & 21.2 & 15.4 & 43.6 & 28.1 & 61.7 \\
\hline Deviation & 0.963 & 0.064 & 0.285 & 0.265 & 0.248 & 0.312 & 0.306 & 0.400 \\
\hline
\end{tabular}

Table 4 shows the time classification of the arrears Livestock Fund for the period (20092018) in all governorates, the average ranges between (6.6 and $14.2 \%$ ), the first period (2009-2013) topped the provinces of Najaf, Anbar, Muthanna and Babylon with ratios of (28.6). 60.4, 26.5, 28.9 and 51\%) respectively, but the lowest for the same period were in both Anbar and Muthanna in 2009 at a rate of $(0 \%)$, and Muthanna continues to be zero for the year 2010, in 2011 ,Dhi Qar (0.5\%), Dhi Qar (0\%)

Table4. Time classification of arrears to the Livestock Fund for the period (2009-2018)

\begin{tabular}{|c|c|c|c|c|c|c|c|c|c|c|}
\hline The province & $\% 2009$ & $\% 2010$ & $\% 2011$ & $\% 2012$ & $\% 2013$ & $\% 2014$ & $\% 2015$ & $\% 2016$ & $\% 2017$ & $\% 2018$ \\
\hline Nineveh & 5.1 & 4.8 & 7.0 & 24.6 & 3.1 & 12.5 & 0 & 0 & 0 & \\
\hline Salahdeen & 4.7 & 5.9 & 4.7 & 0.7 & 7.3 & 0.9 & 8.5 & 3.7 & 0.1 & 20.3 \\
\hline Diyala & 2.5 & 3.2 & 3.2 & 6.0 & 0.5 & 13.1 & 0.1 & 9.4 & 18.5 & 4.9 \\
\hline Kirkuk & 0.5 & 0.5 & 0.9 & 0.4 & 0.1 & 0.5 & 7.8 & 0.1 & 0.1 & 0.0 \\
\hline Baghdad & 0.4 & 27.7 & 5.1 & 1.8 & 2.8 & 9.9 & 11.7 & 24.2 & 9.3 & 6.9 \\
\hline Babylon & 7.7 & 31.3 & 7.0 & 8.9 & 51.0 & 9.1 & 12.0 & 23.8 & 8.9 & 4.1 \\
\hline Karbala & 7.1 & 4.8 & 1.8 & 0.8 & 5.6 & 12.8 & 2.2 & 1.6 & 13.5 & 4.3 \\
\hline Al najaf & 28.6 & 0.3 & 8.5 & 0.0 & 1.4 & 1.2 & 14.6 & 6.8 & 5.0 & 0.4 \\
\hline Kadisiya & 4.3 & 1.0 & 1.2 & 0.1 & 2.2 & 12.4 & 0.0 & 1.9 & 13.5 & 0.3 \\
\hline Anbar & 0.0 & 60.4 & 8.1 & 11.0 & 22.7 & 0.0 & 10.1 & 0.0 & 0.0 & 0.0 \\
\hline Dhi Qar & 0.5 & 4.8 & 0.5 & 0.5 & 0.0 & 5.2 & 3.9 & 0.4 & 7.5 & 9.8 \\
\hline Al-Muthanna & 0.0 & 0.0 & 26.5 & 28.9 & 1.3 & 1.9 & 0.0 & 8.8 & 1.2 & 0.0 \\
\hline Maysan & 0.5 & 4.8 & 4.5 & 4.9 & 0.8 & 0.0 & 16.1 & 9.4 & 3.3 & 24.1 \\
\hline Basra & 14.4 & 4.8 & 18.0 & 0.1 & 0.9 & 12.2 & 13.1 & 8.4 & 11.6 & 4.6 \\
\hline Wasit & 23.8 & 26.5 & 3.0 & 11.2 & 0.2 & 8.4 & 100.0 & 1.5 & 7.4 & 20.4 \\
\hline Average & 6.6 & 12.0 & 6.6 & 6.6 & 6.6 & 6.67 & 14.2 & $7.14 \%$ & 7.14 & 7.1 \\
\hline Deviation & 0.089 & 0.17 & 0.070 & 0.091 & 0.135 & 0.054 & 0.253 & 0.080 & 0.058 & 0.084 \\
\hline
\end{tabular}


Table 5 shows the ratio of delinquent loan collection to total outstanding loans to the Livestock Fund for the period (2009-2018) in all governorates, the highest average value was in 2010 (6.67) and the lowest value was in 2009 (0.9), for the period (2009-2013) Wasit Governorate in 2009 topped by $(3.2 \%)$, the first Anbar governorate in 2010 by (33.4\%), Muthanna in 2011 and 2012 by $(7.8,5.6 \%)$, the lowest percentages were in both Anbar and Muthanna, Kirkuk Baghdad, Maysan Dhi Qar
(0\%), 2010 Al-Muthanna (0\%), in 2011 Dhi Qar ranked last $(0.1 \%)$, in 2012 the governorates of Najaf and Basra (0\%), in 2013 Dhi Qar (0\%), the second term (2014-2016)) The highest percentages were in Ninewa governorate in 2014 by $(5.1 \%)$ and Najaf in 2015 by (3.9\%), the first Baghdad governorate in 2016 by $(10.4 \%)$, on the other side, governorates with low percentages in Maysan Governorate (0\%) in 2014 and 2015 , And Wasit Governorate in $2016(0.6 \%)$.

Table 5. Ratio of delinquent loans to total outstanding loans of the Livestock Fund for the period (2009-2016).

\begin{tabular}{|c|c|c|c|c|c|c|c|c|}
\hline The province & $\% 2009$ & $\% 2010$ & $\% 2011$ & $\% 2012$ & $\% 2013$ & $\% 2014$ & $\% 2015$ & $\% 2016$ \\
\hline Nineveh & 0.7 & 2.7 & 1.9 & 4.8 & 0.4 & 5.1 & 0.0 & $\mathbf{0}$ \\
\hline Salahdeen & 0.6 & 3.2 & 1.3 & 0.1 & 0.9 & 0.3 & 0.0 & 1.6 \\
\hline Diyala & 0.3 & 1.8 & 0.8 & 1.1 & 0.0 & 5.3 & 2.0 & 4.0 \\
\hline Kirkuk & 0.07 & 0.2 & 0.2 & 0.0 & 0.0 & 0.2 & 0.0 & 0.0 \\
\hline Baghdad & 0.06 & 15.3 & 1.4 & 0.3 & 0.3 & 4.0 & 1.9 & 10.4 \\
\hline Babylon & 1.0 & 17.3 & 1.9 & 1.7 & 6.8 & 3.7 & 2.8 & 10.3 \\
\hline Karbala & 1 & 2.6 & 0.4 & 0.1 & 0.7 & 5.2 & 2.9 & 0.7 \\
\hline Alnajaf . & 3.9 & 0.1 & 2.3 & 0.0 & 0.2 & 0.5 & 0.5 & 2.9 \\
\hline Al qadisia & 0.6 & 0.5 & 0.3 & 0.0 & 0.3 & 5.0 & 3.5 & 0.8 \\
\hline Anbar & 0.0 & 33.4 & 2.2 & 2.1 & 3.0 & 0.0 & 0.0 & 0.0 \\
\hline Dhi Qar & 0.07 & 2.6 & 0.1 & 0.1 & 0.0 & 2.1 & 2.4 & 0.1 \\
\hline Al-Muthanna & 0.00 & 0.0 & 7.3 & 5.6 & 0.2 & 0.8 & 0.9 & 3.8 \\
\hline Maysan & 0.07 & 2.6 & 1.2 & 0.9 & 0.1 & 0.0 & 0.0 & 4.0 \\
\hline Basra & 1.97 & 2.6 & 5.0 & 0.0 & 0.1 & 5.0 & 3.9 & 3.6 \\
\hline Wasit & 3.2 & 14.6 & 0.8 & 2.1 & 0.0 & 3.4 & 3.2 & 0.6 \\
\hline Average & 0.9 & 6.6 & 1.8 & 1.3 & 0.9 & 2.7 & 1.6 & 3.0 \\
\hline Deviation & 0.012 & 0.095 & 0.019 & 0.018 & 0.018 & 0.022 & 0.015 & 0.035 \\
\hline
\end{tabular}

Table 6 shows the value of the achievement index of the livestock fund for the period (2009-2018) in all governorates, the first period (2009-2013) the highest average value for the year 2017 was (0.61) with a standard deviation of (0.78), and the lowest value for the average was $2010(0.14)$, the highest values of the achievement index were in the provinces of Maysan and Baghdad for the year 2009 (1), Baghdad continues to lead in 2010 (0.27), and in the first year 2011 the province of Babylon with a value of (0.84) and 2012 the first province of Maysan (0.82), and in 2013 Diyala tops the rest of the governorates with a value of (0.85), the lowest percentages were in 2009 and 2010 in Muthanna Governorate (0), in 2011 Karbala Governorate (0.1), 2012 Najaf (0), 2013 Dhi Qar (0.01), the second term (2014-2018) The highest average was in 2014 (0.50) and the lowest value was (0.23) in 2018, the highest achievement index was in Diyala Governorate (0.76) and the lowest value in Anbar and Maysan Safra in 2014, and in the following year 2015, the first Maysan Governorate (1) and Muthanna (0) In Salah alDin Governorate, Kirkuk, and Dhi Qar, the first ranks for the years 2016, 2017, and 2018 were the highest values $(1,0.85,1)$, the lowest values were in both Maysan and Al-Muthanna governorates with a value of (0) per This above. 


\begin{tabular}{|c|c|c|c|c|c|c|c|c|c|c|}
\hline $\begin{array}{l}\text { The } \\
\text { province }\end{array}$ & 2009 & 2010 & 2011 & 2012 & 2013 & 2014 & 2015 & 2016 & 2017 & 2018 \\
\hline Nineveh & 0.60 & 0.23 & 0.49 & 0.75 & 0.18 & 0.76 & 0.00 & $\mathbf{0}$ & & 0.00 \\
\hline Salahdeen & 0.79 & 0.11 & 0.50 & 0.08 & 0.81 & 0.61 & 0.36 & 0.85 & 0.21 & 0.30 \\
\hline Diyala & 0.25 & 0.08 & 0.27 & 0.24 & 0.07 & 0.61 & 0.06 & 0.45 & 0.82 & 0.52 \\
\hline Kirkuk & 0.25 & 0.08 & 0.32 & 0.18 & 0.85 & 0.56 & 0.33 & 0.15 & 1.00 & 0.00 \\
\hline Baghdad & 0.03 & 0.16 & 0.25 & 0.06 & 0.19 & 0.55 & 0.33 & 0.76 & 0.76 & 0.33 \\
\hline Babylon & 0.15 & 0.20 & 0.84 & 0.27 & 0.83 & 0.43 & 0.79 & 0.57 & 0.53 & 0.13 \\
\hline Karbala & 0.11 & 0.03 & 0.10 & 0.04 & 0.45 & 0.70 & 0.60 & 0.13 & 0.77 & 0.11 \\
\hline Al najaf & 0.66 & 0.00 & 0.72 & 0.00 & 0.27 & 0.64 & 0.59 & 0.78 & 0.86 & 0.13 \\
\hline Al qadisia & 0.20 & 0.01 & 0.13 & 0.01 & 0.30 & 0.62 & 0.00 & 0.10 & 0.62 & 0.03 \\
\hline Anbar & 0.00 & 0.41 & 0.44 & 0.35 & 0.36 & 0 & 0.59 & 0.00 & 0.00 & 0.00 \\
\hline Dhi Qar & 0.07 & 0.20 & 0.18 & 0.12 & 0.01 & 0.55 & 0.39 & 0.02 & 0.44 & 1. \\
\hline $\begin{array}{l}\text { Al- } \\
\text { Muthanna }\end{array}$ & 0.00 & 0.00 & 0.77 & 0.27 & 0.21 & 0.28 & 0.00 & 0.44 & 0.17 & 0.00 \\
\hline Maysan & 1.00 & 0.27 & 0.77 & 0.82 & 0.44 & 0.00 & 1.10 & 0.60 & 0.78 & 0.00 \\
\hline Basra & 0.49 & 0.08 & 0.82 & 0.007 & 0.53 & 0.61 & 0.70 & 0.34 & 0.64 & 0.11 \\
\hline Wasit & 0.20 & 0.19 & 0.20 & 0.52 & 0.02 & 0.56 & 0.51 & 0.84 & 0.86 & 0.61 \\
\hline Average & 0.32 & 0.14 & 0.46 & 0.48 & 0.37 & $\mathbf{0 . 5 0}$ & 0.43 & 0.43 & 0.61 & 0.23 \\
\hline Standard & 0.313 & 0.117 & 0.270 & 0.782 & 0.285 & 0.231 & 0.323 & 0.312 & 0.299 & 0.327 \\
\hline
\end{tabular}

The research concluded that noticeable increase in both poultry meat growth rates for the period (2008-2018) compared to the first period (2000-2008), and there is an increase in the production of table eggs in the second period (2008-2018) compared to the first period (2000-2008) . Also the number of cows of all kinds (local and imported) increased in the period after the launch of the Agricultural Initiative loans (2008-2018) by a small percentage compared to the increase in the number of local buffalo in all governorates covered by the lending policy where the total number of buffaloes in 2002 was (128000) head, While 216965 heads rose in 2018. In addition, fish meat production increased from 16,015 tons in 2002 to 75,719 tons in 2018 as a result of the introduction of both fish farming in floating cages and the closed intensive method as well as the prevailing traditional methods in which the livestock fund had a prominent role in its development. The rate of self-sufficiency in red meat of various types is higher than $60 \%$ in the years after the launch of the agricultural initiative loans, while it did not exceed $55 \%$ in the previous period (2008 or less), and the self-sufficiency rate for white meat was the highest in 2016 and 2017 by $91 \%$, while the highest rate in the first period (2000-2008) was 2000, at 79\%. The highest rates of self-sufficiency in the production of table eggs in Iraq were in the period (20092012), the highest in 2011 , at $62.6 \%$, and then returned to decline as a result of infections of the most prominent fields of table eggs production in the $\mathrm{H} 1 \mathrm{~N} 1$ virus and its exit from production. Also, research concluded the collection rate of the livestock fund loans is very good, which is higher than $70 \%$ in all governorates except the province of Ninawa and Salah al-Din for the period (2009-2013), but it decreased to less than $50 \%$ for the period (2014-2018) and the reason is due to the events that occurred in it as well as decisions Repeated postponement of all loans within the federal budget law. The rate of late loan collection for the Livestock Fund is low in all governorates for the period studied (20092016), as the average did not exceed $62 \%$ in 2016, and the lowest average was in 2010 by $4.5 \%$. The reason for this is that the projects that have been slow to repay are either Their rates of achievement and operation are low from the beginning, or are poorly managed and subject to repeated epidemiological injuries. Finally, the average coefficient for the time classification of arrears ranges between (6.614.2) for the first period 2009-2013) while the second period was the average (6.6-7.1) and the reason is due to what we referred to in the seventh paragraph, and the achievement index of the livestock fund is generally high for all governorates, averages are higher than $30 \%$ for all years except for (2010 and 2018) where they were $(14,23)$ consecutively. Based on conclusions, research recommended to prepare a plan based on the self-sufficiency ratios of all agricultural products, both plant and 
animal, by the relevant authorities to focus loans on the low self-sufficiency ratios to support them in line with the actual need and reduce or cancel loans for agricultural products with high self-sufficiency rates taking into consideration the annual change Those proportions. Also based on the prevailing food pattern domestically and the prevailing customs and traditions that prefer to consume fresh meat, usually red and white, slaughtered in the Islamic way and from reliable sources that helped stabilize prices at high rates (economically feasible). In addition, continued support to poultry projects (white meat, table eggs, hatcheries, feed plants) by continuing to grant low-interest loans with banking facilities and reducing routine in obtaining them, since this policy has proven its worth in raising rates of growth rates in the second period (project launch period) Agricultural initiative) than it was in the first period. Re-examine the loans granted to local cows stations and set an action plan to target the obstacles that prevented the preparation of local cows to growth compared to the growth rates of buffalo numbers, even though the loans granted are greater than the loans granted to cows. Directing a greater percentage of loans to develop and develop fish meat production for each of the methods (floating cages and closed breeding) to respond directly to the direct volume of loans granted, as the local demand helps to absorb larger quantities of fish meat for preference by the consumer, the prevailing nutritional pattern, and the rate of profits to rise Their prices throughout the year. Continued support to fattening projects for calves and lambs as a loan due to the low levels of self-sufficiency of red meat, despite its continuous progress during the years of launching the fund for animal wealth, where the highest level of sufficiency reached $60 \%$. Continued support and development of breeding projects for broilers, hatcheries, eggs for hatching eggs and feed plants for the local need and the increasing demand for them and lack of access to self-sufficiency during the years that saw the support and lending of these projects, where the highest level of sufficiency reached $91 \%$. Allocating specific percentages of the livestock fund loans to continue to support the establishment and expansion of table egg production projects because of the low rates of self-sufficiency, the highest of which was $62 \%$ due to the projects' exposure to injuries and the closure of some of them even though the prices of eggs produced locally from the importer with the consumer preference for the product locally at the importer's account . Continuing to follow up the implementation and operation of the financed projects, especially those that are lagging in their payment and take measures in a manner appropriate to the status of the current project, either to direct and evaluate the investor's performance or to take legal action with the prescribed penalties in case the investor is not serious and willing to implement and operate. Finally, re-evaluation of projects in the governorates that witnessed security incidents after 2014 (Al-Anbar, Salah Al-Din, Nineveh, Diyala, North Babylon, and the Baghdad Belt) and looking into the possibility of requalifying and operating them based on the rates of damage as they are the reason behind the decrease in the rates of all studied standards after a year 2014.

\section{REFERENCES}

1. Abd-Hago, N. N. 2018. Reform of the Livestock Sector - Problems and Solutions, Center for Public Policy Governance, an organization registered with the department of Non-Governmental Organizations.

2. Agricultural Cooperative Bank / General Center - Agricultural Planning

3. Al-Atabi, H. A. and B. H. Al-Badri. 2014. Evaluation of the performance of the agricultural cooperative bank and its role in planning for sustainable development in Iraq. Journal of the Baghdad College of Economic Sciences University. Issue No. 5 of the 2014 Scientific Conference. p161

4. Al-Barzanji, A. M. F. S. 2019. Introduction to Finance and Investment, Dar Al-Doctor for Administrative and Economic Sciences. $2^{\text {nd }}$ Edition, Baghdad Al-Mutanabi Street. p 21

5. Al-Khafaji, R. F. M. 2018. An Economic Study of The Effect of Some Agricultural Policies on The Major Cereal Crops in Iraq during the period (1994-2015). Ph.D. dissertation, Dept. of Agricultural economics., Coll. of Agric., Univ. of Baghdad. pp. 1

6. Al-Taie, K. H. 2010. Evaluating the Performance of the Iraqi Agricultural 
Cooperative Bank through the Achievement Efficiency of Loans and Attracting Savings for the period (2003-2008). M.Sc. Thesis, Dept. of Agricultural Economics., Coll. of Agric., Univ. of Baghdad. pp. 36

7. Bank of Uganda. 2015. Monetary of Agriculture, Agricultural Finance. year book. pp. 123-126

8. Barbaz, D. S. 2014. Economic evaluation of producing wheat at Al- Abaichi farm. Iraqi journal of agricultural sciences. 45(2):165-173 9. Barbaz, D. S. and A. D. K. Al- Hiyali. 2020. Economic evaluation of some agricultural imitative projects in Iraq. Iraqi journal of agricultural sciences. 51(3):797-804

10. Barbaz, D. S. and J.H. Al Ezzy. 2012. Efficiency of projects of green house in the governor of Karbala in 2009-2010 . Iraqi journal of agricultural sciences 43(4):70-74 11. Brady, E. B. and et.al. 2014. Multiple vs. single lending relationships in the agriculture sector, agricultural finance review. Vol.74 no 2014. pp.55-68
12. Fares, A. M. 2005. The Foundations of Agricultural Lending and Cooperative Finance, Umar Al-Mukhtar University Publications. Al-Bayda. pp. 22

13. Ministry of Planning - Central Organization for Statistics / Agricultural Statistics

14. Prime Minister Office- the Higher Commotion of Agricultural Initiative Office

15. Prime Minister's Office - the Executive Office of the Higher Committee for the Agricultural Initiative

16. Sarkar, M.S.K and et.al. 2010. Comparative economic analysis of borrower and non- barrower Boro rice farmer in some selected sites of Mymensingh district. Bangladesh. J. agri. Res. 35(1): 65-76

17. Saima, A.S and et.al.2011. Role of agricultural credit on production efficiency of farming sector in Pakistan -a date envelopment analysis. Pak. J. life sos. Sci. 2011. 9(1): 38-44 18. The Ministry of Agriculture - Agricultural Statistics and the Planning and Follow-up Department. 